\title{
Air Pollution Index Trend Analysis in Malaysia, 2010-15
}

\author{
Nurul Latiffah Abd Rani ${ }^{1}$, Azman Azid ${ }^{1 *}$, Saiful Iskandar Khalit ${ }^{1}$, \\ Hafizan Juahir ${ }^{2}$, Mohd Saiful Samsudin ${ }^{1}$
}

\author{
${ }^{1}$ Faculty Bioresources and Food Industry, Universiti Sultan Zainal Abidin, Besut Campus, \\ 22200 Besut, Terengganu, Malaysia \\ ${ }^{2}$ East Coast Environmental Research Institute (ESERI), Universiti Sultan Zainal Abidin, \\ Gong Badak Campus, 21300 Kuala Terengganu, Terengganu, Malaysia
}

Received: 4 April 2017

Accepted: 18 July 2017

\begin{abstract}
Air pollution index (API) is used in Malaysia to determine the level of air quality. API is based on the calculation consist of pollutants $\mathrm{PM}_{10}, \mathrm{O}_{3}, \mathrm{CO}_{2}, \mathrm{SO}_{2}$, and $\mathrm{NO}_{2}$. Unhealthy air quality can harm human health and the environment as well as property. In view of this fact, a study of air pollution trend analysis in Malaysia from 2010 to 2015 was performed with the objective of determining the API trend in Malaysia from 2010 to 2015. A dataset of API value was obtained from the Air Quality Division, Department of Environment Malaysia (DOE). In this study, 19,872 datasets for all Malaysian air quality monitoring stations that had API value greater than 100 and a total of 52,584 datasets for Muar District in Johor were used. XLSTAT add-in 2014 was used to analyze the API hourly reading. Analysis shows that the air monitoring station at Sekolah Menengah Teknik Muar in Johor shows the highest value of API reading with 663 on 23 June 2013 (emergency level), where on that day Malaysia faced its worst air quality due to haze episodes. Other locations also show the worst air quality with API registering at unhealthy, very unhealthy, and hazardous levels.
\end{abstract}

Keywords: air pollution index (API), trend analysis, Malaysia, 2010 to 2015

\section{Introduction}

By the year 2020 Malaysia will have forged ahead to become an industrialized nation. Thus, air quality in Malaysia is a major concern according to that determination. Factories, power plants, dry cleaner, vehicles, windblown dust, and wildfires are examples of various sources that contribute to air pollution [1]. Air pollution monitoring duties are disseminated at

*e-mail: azmanazid@unisza.edu.my different levels that consist of protocols and international agreements, and community legislation at the national and regional levels [2].

Air quality guidelines for air pollutants were formulated by the Malaysian Department of the Environment (DOE) in 1989. The Recommended Malaysian Air Quality Guidelines (RMG) defined concentration limits of selected air pollutants that might adversely affect the general public's health and welfare. In 1993 the DOE established its first air quality index system, known as the Malaysian Air Quality Index (MAQI), and played an important role in informing both decision makers 
Table 1. Air pollution index (API) status indicator.

\begin{tabular}{|c|c|}
\hline API & DESCRIPTOR \\
\hline $0-50$ & Good \\
\hline $51-100$ & Moderate \\
\hline $101-200$ & Unhealthy \\
\hline $201-300$ & Very unhealthy \\
\hline$>300$ & Hazardous \\
\hline$>500$ & Emergency \\
\hline
\end{tabular}

Source: DOE (2000) [3]

and the general public about ambient air quality status ranging from good to emergency. By applying this index particularly in industrialized countries, the management of air quality and public health protection has become effective. In 1996 DOE Malaysia revised its index system for easy evaluation with countries as well as for regional harmonization where the air pollution index (API) was adopted, which closely follows the United States system known as pollutant standard index (PSI) [3]. PSI is one of the first synthetic indices agreed to by the United States Environmental Protection Agency (USEPA) as developed by Ott and Hunt [4]. However, in 1999 the EPA changed replaced PSI with air quality index (AQI) while Malaysia stuck with API.

The status indicator of API was divided into a few categories. For instance, good, moderate, unhealthy, very unhealthy, hazardous, and emergency as mentioned in Table 1 [3], which can be of air quality management level or decision making for data interpretation processes. In this paper, API was applied to all states in Malaysia for the purposes of evaluating air quality trends from 2010 to 2015. Changes in air quality over the considered period are analyzed.

The index system known as API is a simple comprehensive approach for defining air quality status that can be understood easily by the general public. It is categorized based on the highest values from five main air pollutants index values: particulate matter $<10 \mu \mathrm{m}\left(\mathrm{PM}_{10}\right)$, ozone $\left(\mathrm{O}_{3}\right)$, carbon monoxide $(\mathrm{CO})$, sulphur dioxide $\left(\mathrm{SO}_{2}\right)$, and nitrogen dioxide $\left(\mathrm{NO}_{2}\right)$ for a particular time period, and where $\mathrm{PM}_{10}$ and $\mathrm{SO}_{2}$ hourly value are averaged over a 24-hour running period, $\mathrm{CO}$ is averaged over an eight-hour period, and $\mathrm{O}_{3}$ and $\mathrm{NO}_{x}$ are read hourly before an hourly index is calculated with the use of sub-index functions for each pollutant according to the standpoint of human health implications. All the sub-indices of pollutants can be calculated as shown in Table 2. Individual indices were calculated based on individual pollutants. The maximum index among the pollutants was selected. That index is then considered as API.

Each pollutant has a different impact on human health. For instance, PM can cause lung cancer and cardiopulmonary deaths while $\mathrm{O}_{3}$ can reduce lung function and induce coughing and choking. The presence of $\mathrm{CO}$ can cause mortal growth in pregnant women as well as affect tissue development of young children [5]. A non-irritating gas such as NO may irritate respiratory infections with indications like a cough, sore throat, nasal congestion, and fever while $\mathrm{SO}_{2}$ can narrow the airways for people with asthma and shortness of breath [6].

This has been proven by statistics done by the Ministry of Health Malaysia, where $10.36 \%$ of the statistic come from respiratory system diseases and $19.48 \%$ is

Table 2. API equation for each pollutant.

\begin{tabular}{|c|c|c|}
\hline Pollutant & \multicolumn{2}{|c|}{ API calculation equation } \\
\hline $\begin{array}{c}\text { CO } \\
\text { (Based on eight-hour average concentration) }\end{array}$ & $\begin{array}{l}\text { conc }<9 \text { ppm } \\
9<\text { conc. }<15 \\
15<\text { conc. }<30 \\
\text { conc. }>30 \text { ppm }\end{array}$ & $\begin{array}{l}\text { API }=\text { conc. } \times 11.11111 \\
\text { API }=100+\{[\text { conc. }-9] \times 16.66667 \backslash \\
\text { API }=200+\{[\text { conc. }-15] \times 6.66667] \\
\text { API }=300+\{[\text { conc. }-30] \times 10]\end{array}$ \\
\hline $\begin{array}{c}\mathrm{O}_{3} \\
\text { (Based on one-hour average concentration) }\end{array}$ & $\begin{array}{l}\text { conc }<0.2 \mathrm{ppm} \\
0.2<\text { conc. }<0.4 \\
\text { conc. }>0.4 \mathrm{ppm}\end{array}$ & $\begin{array}{l}\text { API }=\text { conc. } \times 1000 \\
\text { API }=200+\{[\text { conc. }-0.2] \times 500] \\
\text { API }=300+\{[\text { conc. }-0.4] \times 1000]\end{array}$ \\
\hline $\begin{array}{c}\mathrm{NO}_{2} \\
\text { (Based on one-hour average concentration) }\end{array}$ & $\begin{array}{l}\text { conc }<0.17 \mathrm{ppm} \\
0.17<\text { conc. }<0.6 \\
0.6<\text { conc. }<1.2 \\
\text { conc. }>1.2 \mathrm{ppm}\end{array}$ & $\begin{array}{l}\text { API }=\text { conc. } \times 588.23529 \\
\text { API }=100+\{[\text { conc. }-0.17] \times 232.56] \\
\text { API }=200+\{[\text { conc. }-0.6] \times 166.667] \\
\text { API }=300+\{[\text { conc. }-1.2] \times 250]\end{array}$ \\
\hline $\begin{array}{c}\mathrm{SO}_{2} \\
\text { (Based on 24-hour } \\
\text { average concentration) }\end{array}$ & $\begin{array}{l}\text { conc }<0.04 \mathrm{ppm} \\
0.04<\text { conc. }<0.3 \\
0.3<\text { conc. }<0.6 \\
\text { conc. }>0.6 \mathrm{ppm}\end{array}$ & $\begin{array}{l}\mathrm{API}=\text { conc. } \times 2500 \\
\mathrm{API}=100+\{[\text { conc. }-0.04] \times 384.61] \\
\mathrm{API}=200+\{[\text { conc. }-0.3] \times 333.333] \\
\mathrm{API}=300+\{[\text { conc. }-0.6] \times 500]\end{array}$ \\
\hline $\begin{array}{c}\mathrm{PM}_{10} \\
\text { (Based on 24-hour } \\
\text { average concentration) }\end{array}$ & $\begin{array}{l}\text { conc }<50 \mathrm{pg} / \mathrm{m}^{3} \\
50<\text { conc. }<150 \\
150<\text { conc. }<350 \\
350<\text { conc. }<420 \\
420<\text { conc. }<500 \\
\text { conc. }>500 \mathrm{pg} / \mathrm{m}^{3}\end{array}$ & $\begin{array}{l}\text { API }=\text { conc. } \\
\text { API }=50+\{[\text { conc. }-50] \times 0.5] \\
\text { API }=100+\{[\text { conc. }-150] \times 0.5] \\
\text { API }=200+\{[\text { conc }-350] \times 14286] \\
\text { API }=300+\{[\text { conc. }-420] \times 1.25] \\
\text { API }=400+[\text { conc. }-500]\end{array}$ \\
\hline
\end{tabular}


the principal cause of death due to respiratory system disease. It then lists the 10 highest reasons of death and for hospital admission [7].

The advantage of using API for policies and regulatory action is that the index can reveal air quality status and its effects on human health. Thus, an action can be implemented as soon as possible once worst air quality is detected. According to [8], the air pollution index has been known as one of the important indicators of air quality that used to record the correlation between air pollution and human health.

However, it also has a drawback since the API value is only based on the highest sub-index value. $\mathrm{PM}_{10}$ subindex pollutant has always been taken as it is present in great concentration compared to other pollutants. This is supported by the research done by [9-11], where according to their study $\mathrm{PM}_{10}$ is the main contributor to the air pollutant measurements and contributes to variability in the API. Thus the method for $\mathrm{PM}_{10}$, which is AS 2724.6, was applied to determine air quality guidelines [3] with a value of recommended by Malaysian Air Quality Guidelines (RMAQG) of $150 \mu \mathrm{g} / \mathrm{m}^{3}$ and $50 \mu \mathrm{g} / \mathrm{m}^{3}$ for average time of $\mathrm{PM}_{10} 24$ hours and one year, respectively. Compared with other pollutants, $\mathrm{PM}_{10}$ concentration was categorized as a main contributor to the air pollutant measurement, and supposedly other pollutants also need be considered as each pollutant plays its role in spreading different types of impact on human health.

\section{Material and Methods}

\section{Study Area}

Ambient air quality was monitored continuously by DOE using their monitoring station network. There are 50 continuous monitoring stations throughout Malaysia (Table 3). However, in this study the monitoring station only focuses on Sekolah Menengah Teknik Muar in Johor, as indicated in Figure 1. It is strategically located in both residential and industrial areas. The dataset was obtained from DOE Malaysia. In this study, the hourly dataset from 2010 to 2015 we used covered Peninsular Malaysia, Sabah, and Sarawak with 50 sampling stations. From the analysis, the sampling station at Sekolah Menengah Teknik Muar in Johor shows the highest API value, among others.

Muar district in Johor was selected for this study due to the high API value present at this location. It is located in northwestern Johor, in which is located a small number of industries although it is considered a residential area. The sampling station was located at Sekolah Menengah Teknik Muar $\left(02^{\circ} 03.715^{\prime} \mathrm{N}, 102^{\circ} 35.587^{\prime}\right)$.

\section{Data Collection}

Air quality trend analysis in Malaysia from 2010 to 2015 is covered in this study. The air quality and

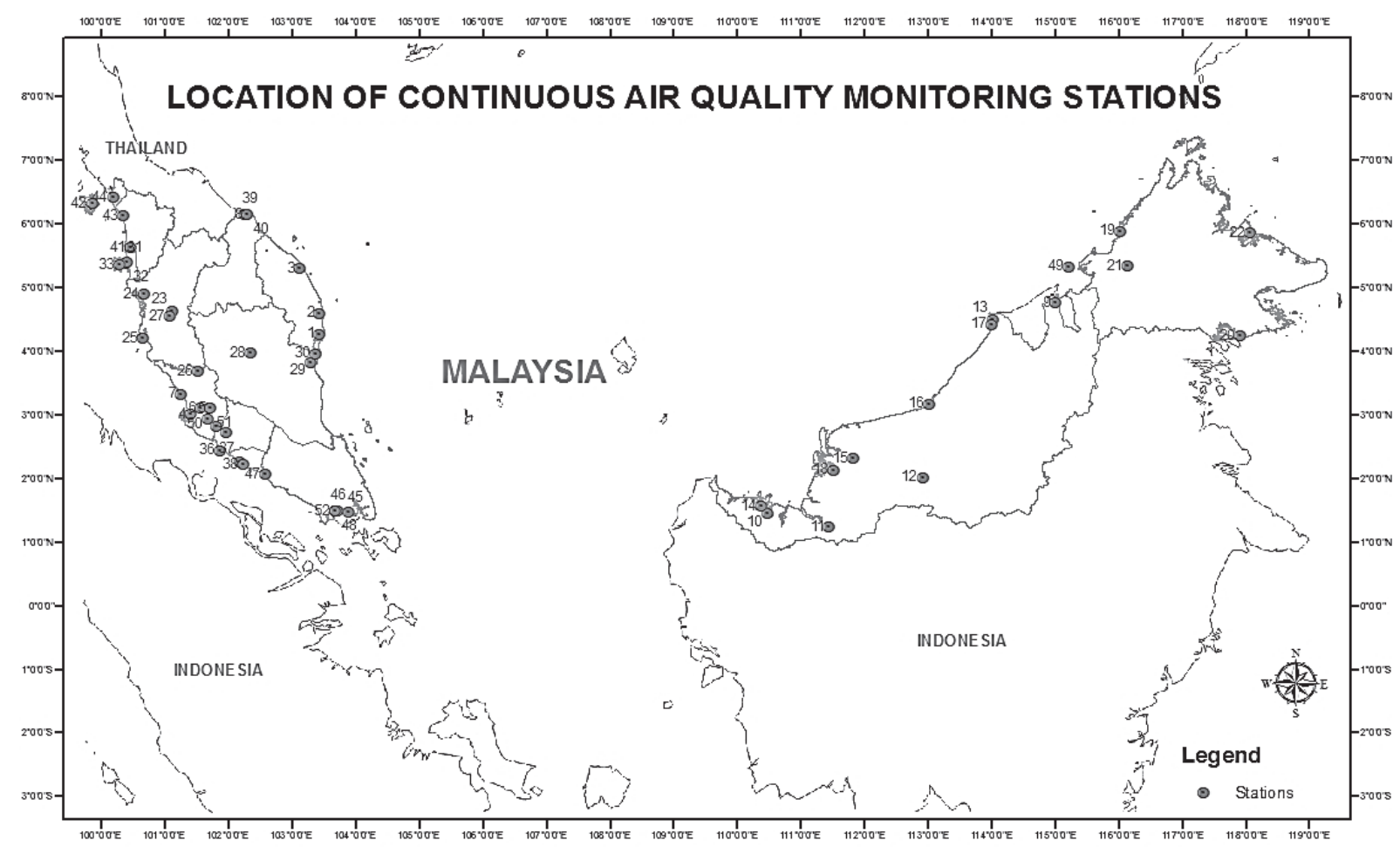

$1: 8,100,000$

Fig. 1. Continuous air monitoring stations in Malaysia - specifically in Muar (Loc. No. 47)

Source : DOE (2004) [12] 
Table 3. Air monitoring stations sampling point.

\begin{tabular}{|c|c|c|c|}
\hline $\begin{array}{l}\text { Loc. } \\
\text { No. }\end{array}$ & Locations & $\begin{array}{l}\text { Latitude } \\
(\mathrm{N})\end{array}$ & $\begin{array}{l}\text { Longitude } \\
\text { (E) }\end{array}$ \\
\hline 1 & $\begin{array}{l}\text { Sek. Ren. Keb. Bukit } \\
\text { Kuang, Teluk Kalung }\end{array}$ & $04^{\circ} 16.260^{\prime}$ & $103^{\circ} 25.826^{\prime}$ \\
\hline 2 & $\begin{array}{l}\text { Kuarters TNB, Paka- } \\
\text { Kertih }\end{array}$ & $04^{\circ} 35.880^{\prime}$ & $103^{\circ} 26.096^{\prime}$ \\
\hline 3 & $\begin{array}{c}\text { Sek. Keb.Chabang Tiga, } \\
\text { Kuala Terengganu }\end{array}$ & $05^{\circ} 18.455^{\prime}$ & $103^{\circ} 07.213^{\prime}$ \\
\hline 4 & $\begin{array}{c}\text { Sekolah Menengah (P) } \\
\text { Raja Zarina, Klang }\end{array}$ & $03^{\circ} 00.602^{\prime}$ & $101^{\circ} 24.484^{\prime}$ \\
\hline 5 & $\begin{array}{l}\text { Sek. Keb. Bandar } \\
\text { Utama, Petaling Jaya }\end{array}$ & $03^{\circ} 06.612^{\prime}$ & $101^{\circ} 42.274^{\prime}$ \\
\hline 6 & $\begin{array}{l}\text { Sek. Keb. TTDI Jaya, } \\
\text { Shah Alam }\end{array}$ & $03^{\circ} 06.286^{\prime}$ & $101^{\circ} 33.367^{\prime}$ \\
\hline 7 & $\begin{array}{c}\text { Sekolah Menengah } \\
\text { Sains, Kuala Selangor }\end{array}$ & $03^{\circ} 19.592^{\prime}$ & $101^{\circ} 15.532^{\prime}$ \\
\hline 8 & Kolej MARA Banting & $02^{\circ} 49.001^{\prime}$ & $101^{\circ} 37.381^{\prime}$ \\
\hline 9 & $\begin{array}{l}\text { Dewan Suarah, } \\
\text { Limbang }\end{array}$ & $04^{\circ} 45.529^{\prime}$ & $115^{\circ} 00.813$ \\
\hline 10 & $\begin{array}{c}\text { Pej. Daerah, Kota } \\
\text { Samarahan, Sarawak }\end{array}$ & $01^{\circ} 27.308^{\prime}$ & $110^{\circ} 29.498$ \\
\hline 11 & $\begin{array}{l}\text { Kompleks Sukan, Sri } \\
\text { Aman }\end{array}$ & $01^{\circ} 14.425^{\prime}$ & $111^{\circ} 27.629^{\prime}$ \\
\hline 12 & Stadium Tertutup, Kapit & $02^{\circ} 00.875^{\prime}$ & $112^{\circ} 55.640$ \\
\hline 14 & $\begin{array}{c}\text { Medical Store, } \\
\text { Kuching, Sarawak }\end{array}$ & $01^{\circ} 33.734^{\prime}$ & $110^{\circ} 23.329$ \\
\hline 15 & $\begin{array}{c}\text { Ibu Pej. Polis Sibu, } \\
\text { Sarawak }\end{array}$ & $02^{\circ} 18.856^{\prime}$ & $111^{\circ} 49.906$ \\
\hline 16 & $\begin{array}{l}\text { Balai Polis Pusat } \\
\text { Bintulu, Sarawak }\end{array}$ & $03^{\circ} 10.587^{\prime}$ & $113^{\circ} 02.433$ \\
\hline 17 & $\begin{array}{l}\text { Sek. Men Dato' } \\
\text { Permaisuri Miri, } \\
\text { Sarawak }\end{array}$ & $04^{\circ} 25.456^{\prime}$ & $114^{\circ} 00.731$ \\
\hline 18 & $\begin{array}{l}\text { Balai Polis Pusat } \\
\text { Sarikei, Sarawak }\end{array}$ & $02^{\circ} 07.992^{\prime}$ & $111^{\circ} 31.351$ \\
\hline 19 & $\begin{array}{l}\text { Sek. Men. Keb. Putatan, } \\
\text { Kota Kinabalu }\end{array}$ & $05^{\circ} 53.623^{\prime}$ & $116^{\circ} 02.596^{\prime}$ \\
\hline 20 & $\begin{array}{c}\text { Pejabat JKR, Tawau, } \\
\text { Sabah }\end{array}$ & $04^{\circ} 15.016^{\prime}$ & $117^{\circ} 56.166^{\prime}$ \\
\hline 21 & $\begin{array}{c}\text { Sek. Men. Keb. } \\
\text { Gunsanad, Keningau, } \\
\text { Sabah }\end{array}$ & $05^{\circ} 20.313^{\prime}$ & $116^{\circ} 09.769^{\prime}$ \\
\hline 22 & $\begin{array}{c}\text { Pej JKR Sandakan, } \\
\text { Sandakan } \\
\end{array}$ & $05^{\circ} 51.865^{\prime}$ & $118^{\circ} 05.479^{\prime}$ \\
\hline 23 & $\begin{array}{l}\text { Sek. Men Jalan Tasek, } \\
\text { Ipoh }\end{array}$ & $04^{\circ} 37.781^{\prime}$ & $101^{\circ} 06.964^{\prime}$ \\
\hline 24 & $\begin{array}{l}\text { Sek. Men. Keb. Air } \\
\text { Puteh, Taiping }\end{array}$ & $04^{\circ} 53.940^{\prime}$ & $100^{\circ} 40.782^{\prime}$ \\
\hline 25 & $\begin{array}{c}\text { Pejabat Pentadbiran } \\
\text { Daerah Manjung, Perak }\end{array}$ & $04^{\circ} 12.038^{\prime}$ & $100^{\circ} 39.841^{\prime}$ \\
\hline 26 & UPSI, Tanjung Malim & $03^{\circ} 41.267^{\prime}$ & $101^{\circ} 31.466^{\prime}$ \\
\hline 27 & $\begin{array}{l}\text { Sek. Men. Pagoh, Ipoh, } \\
\text { Perak }\end{array}$ & $04^{\circ} 33.155^{\prime}$ & $101^{\circ} 04.856^{\prime}$ \\
\hline
\end{tabular}

\begin{tabular}{|c|c|c|c|}
\hline 28 & $\begin{array}{l}\text { Pejabat Kaji Cuaca } \\
\text { Batu Embun, Jerantut }\end{array}$ & $03^{\circ} 58.238^{\prime}$ & $102^{\circ} 20.863^{\prime}$ \\
\hline 29 & $\begin{array}{l}\text { Sekolah Kebangsann } \\
\text { Indera Mahkota }\end{array}$ & $03^{\circ} 49.138^{\prime}$ & $103^{\circ} 17.817^{\prime}$ \\
\hline 30 & $\begin{array}{l}\text { Sekolah Kebangsaan } \\
\text { Balok Baru, Kuantan }\end{array}$ & $03^{\circ} 57.726^{\prime}$ & $103^{\circ} 22.955^{\prime}$ \\
\hline 31 & $\begin{array}{c}\text { Sek. Keb. } \\
\text { Cenderawasih, Perai }\end{array}$ & $05^{\circ} 23.470^{\prime}$ & $100^{\circ} 23.213^{\prime}$ \\
\hline 32 & $\begin{array}{c}\text { Sek. Keb. Sebarang } \\
\text { Jaya II, Perai }\end{array}$ & $05^{\circ} 23.890^{\prime}$ & $100^{\circ} 24.194^{\prime}$ \\
\hline 33 & $\begin{array}{c}\text { Universiti Sains } \\
\text { Malaysia, Pulau Pinang }\end{array}$ & $05^{\circ} 21.528^{\prime}$ & $100^{\circ} 17.864^{\prime}$ \\
\hline 35 & $\begin{array}{c}\text { Sek. Men. Teknik } \\
\text { Tuanku Jaafar }\end{array}$ & $02^{\circ} 43.418^{\prime}$ & $101^{\circ} 58.105^{\prime}$ \\
\hline 36 & $\begin{array}{c}\text { Pusat Sumber } \\
\text { Pendidikan Negeri } \\
\text { Sembilan }\end{array}$ & $02^{\circ} 26.458^{\prime}$ & $101^{\circ} 51.956^{\prime}$ \\
\hline 37 & $\begin{array}{l}\text { Sek. Men. Keb. Bukit } \\
\text { Rambai, Melaka }\end{array}$ & $02^{\circ} 15.510^{\prime}$ & $102^{\circ} 10.364^{\prime}$ \\
\hline 38 & $\begin{array}{l}\text { Sek. Men. Tinggi, } \\
\text { Melaka }\end{array}$ & $02^{\circ} 12.789^{\prime}$ & $102^{\circ} 14.055^{\prime}$ \\
\hline 39 & $\begin{array}{c}\text { Sek. Men. Keb. Tanjung } \\
\text { Chat, Kota Bharu }\end{array}$ & $06^{\circ} 09.520^{\prime}$ & $102^{\circ} 15.059^{\prime}$ \\
\hline 40 & SMK Tanah Merah & $05^{\circ} 48.671^{\prime}$ & $102^{\circ} 08.000^{\prime}$ \\
\hline 41 & $\begin{array}{c}\text { Sekolah Kebangsaan } \\
\text { Bakar Arang, Sg Petani }\end{array}$ & $05^{\circ} 37.886^{\prime}$ & $100^{\circ} 28.189^{\prime}$ \\
\hline 42 & $\begin{array}{l}\text { Kompleks Sukan } \\
\text { Langkawi, Kedah }\end{array}$ & $06^{\circ} 19.903^{\prime}$ & $099^{\circ} 51.517^{\prime}$ \\
\hline 43 & $\begin{array}{c}\text { Sek. Men. Agama } \\
\text { Mergong, Alor Setar }\end{array}$ & $06^{\circ} 08.218^{\prime}$ & $100^{\circ} 20.880^{\prime}$ \\
\hline 44 & ILP Kangar & $06^{\circ} 25.424^{\prime}$ & $100^{\circ} 11.046^{\prime}$ \\
\hline 45 & $\begin{array}{l}\text { Sekolah Menengah } \\
\text { Pasir Gudang } 2 \\
\end{array}$ & $01^{\circ} 28.225^{\prime}$ & $103^{\circ} 53.637^{\prime}$ \\
\hline 46 & $\begin{array}{c}\text { Institut Perguruan, } \\
\text { Temenggong Ibrahim }\end{array}$ & $01^{\circ} 28.225^{\prime}$ & $103^{\circ} 53.637^{\prime}$ \\
\hline 47 & $\begin{array}{l}\text { Sek. Men. Teknik Muar, } \\
\text { Muar, Johor }\end{array}$ & $02^{\circ} 03.715^{\prime}$ & $102^{\circ} 35.587^{\prime}$ \\
\hline 48 & $\begin{array}{l}\text { SMA Bandar Penawar, } \\
\text { Kota Tinggi, Johor }\end{array}$ & $01^{\circ} 33.500^{\prime}$ & $104^{\circ} 13.310^{\prime}$ \\
\hline 49 & $\begin{array}{c}\text { Tmn Perumahan Majlis } \\
\text { Perbandaran, Labuan }\end{array}$ & $05^{\circ} 19.980^{\prime}$ & $115^{\circ} 14.315^{\prime}$ \\
\hline 50 & $\begin{array}{c}\text { Sek. Keb. Putrajaya } \\
\text { 8(2), Jln P8/E2, } \\
\text { Putrajaya }\end{array}$ & $02^{\circ} 55.915^{\prime}$ & $101^{\circ} 40.909^{\prime}$ \\
\hline 51 & $\begin{array}{l}\text { Sek. Men. Keb. Seri } \\
\text { Permaisuri, Cheras }\end{array}$ & $03^{\circ} 06.376^{\prime}$ & $101^{\circ} 43.072^{\prime}$ \\
\hline 52 & $\begin{array}{l}\text { Sek. Keb. Batu Muda, } \\
\text { Kuala Lumpur }\end{array}$ & $03^{\circ} 12.748^{\prime}$ & $101^{\circ} 40.929^{\prime}$ \\
\hline
\end{tabular}


meteorological data were obtained from the Air Quality Division of the DOE. Hourly API from each air monitoring station was analysed where API was based on the average concentration of $\mathrm{PM}_{10}, \mathrm{O}_{3}, \mathrm{CO}, \mathrm{SO}_{2}$, and $\mathrm{NO}_{2}$. Analyser series independent of each other were located at each station.

\section{Data Analysis}

The hourly readings were analysed using time series transformation accessed in Excel using the XLSTAT addon statistical software. The analysis consists of 19,872 data set of all Malaysia air quality monitoring stations that had API value greater than 100, while a total of 52,584 dataset was used for Muar district in Johor.

\section{Results and Discussion}

Fig. 2 shows the trend of API greater than 100 from 2010 to 2015 at continuous air monitoring stations in Malaysia. Values of API greater than 100 were analysed in this study as unhealthy, very unhealthy, hazardous, and emergency levels likely to contribute significant damage to health, environment, and property.

From the agglomeration where the monitoring station is located, the trend of API shows that most of the continuous air monitoring stations in Malaysia from 2010 to 2015 are at the unhealthy level compared to very unhealthy, hazardous, and emergency levels. However, some locations were detected at emergency level by continuous air monitoring stations with API value greater than 500 .

The highest API recorded is 663 at Sekolah Menengah Teknik Muar, Johor, which is at the emergency level. Continuous air monitoring stations at Sekolah Menengah Teknik Muar, Johor continuously show API value greater than 500 from 01:00 to 16:00 on 23 June 2013. This might due to the haze episodes experienced in Malaysia due to the transboundary pollution from Indonesian forest fires. Haze is one of the factors made up of $\mathrm{CO}, \mathrm{SO}_{2}, \mathrm{NO}_{2}$, $\mathrm{O}_{3}$, dust, and metals, where these include five major air

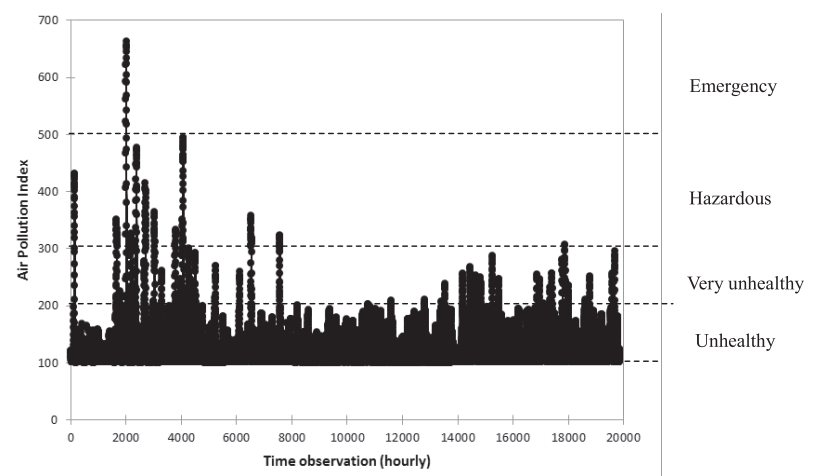

Fig. 2. Air pollution index trend ( $>100)$ from 2010 to 2015 in Malaysia. pollutants in API. Its formation includes several factors, for instance prolonged dry weather, a stable atmosphere, and an abundant pollutant supply from urban or rural sources [13]. At the time, the air monitoring station at Sekolah Menengah Teknik Muar was facing the dry season as it experienced the southwest monsoon, which usually ran from May until September, which brings less rainfall. Besides, the study done by [14] shows that parameters such as $\mathrm{O}_{3}$ and $\mathrm{PM}_{10}$ are responsible for air quality variations. Thus, the presence of these pollutants has its own impact to air quality.

Particulate matter is the main contributor to this situation. This been approved by the study done by [15], where the result from their study shows that during the haze period, the concentration of $\mathrm{PM}_{10}$ is much higher compared to the non-haze period.

Besides, the high API value might be due to the increasing ozone concentrations resulting from the sunrise coinciding with increasing solar radiation. This is proven by the study done by [16], where they found that concentrations of $\mathrm{O}_{3}$ gradually increase after sunrise, coinciding with the increasing solar radiation from 07:00 onward. The analysis found that the API value is high from 01:00 to $16: 00$, equivalent with the study done by [16]. The high value of API above 07:00 in this study might due to this factor.

Continuous air monitoring stations at Johor (SM Teknik Muar, SM Pasir Gudang 2, SMA Bandar Penawar), Melaka (SM Bukit Rambai, SM Tinggi Melaka), Negeri Sembilan (Pusat Sumber Pendidikan Negeri Sembilan), Perak (Pejabat Pentadbiran Daerah Manjung), and Selangor (SM(P) Raja Zarina Klang, SK TTDI Jaya Shah Alam, Kolej MARA Banting) shows that these locations are at a hazardous level according to API level. Most of these locations are in a residential area and certain locations are at the comprehensive and $\mathrm{PM}_{10}$ area. Basically, the residential area does not contribute to the high API. However, analysis shows that the residential area also contributes to the high API value. This incident might be due to air pollutant distribution. According to [17], factors that impact air pollution distribution are wind speed, wind direction, and solar radiation. This supports the statement by [18] that meteorological conditions determine outflow strength, and also depend on megacity geographic location as well as the season for the period of emission. Besides, [18] also states that pollutants experience long-range transport due to their longer lifetimes. For instance, $\mathrm{O}_{3}$ and $\mathrm{PM}$ experience a lifetime in the range of a few hours up to a few weeks, while $\mathrm{CO}$ experienced a lifetime in years. Although located in the residential area, this might be one of the factors that contributes to a high API value.

Besides emergency and hazardous level, unhealthy and very unhealthy levels of API also should be featured as these types of levels also have their own negative contribution to humans and the environment as according to [3], as unhealthy levels give mild symptoms of aggravation among high-risk people, for instance, such as those with lung disease and heart conditions. And for 
very unhealthy level, there are significant aggravation symptoms and reduced exercise tolerance in people with heart or lung disease. In addition, many sources contribute to this API value as [19] reported that major sources in Malaysia are mobile (70-75\%) of total air pollution, stationary sources (20-25\%), and open burning sources (3-5\%). Different levels of API present might be due to the different sources of pollutants present at that place.

Fig. 3 shows the API trend from 2010 to 2015 in Sekolah Menengah Teknik Muar. Most of the sampling locations show API values in the range 0-100, which falls within the good (0-50) and moderate (51-100) categories. Certain locations fall within the unhealthy, very unhealthy, hazardous, and emergency categories. This is shown in Fig. 4a), which shows a high frequency of good and moderate API levels from 2010 to 2015.

There are certain data falls within the emergency level that on 23 June 2013 ran from 01:00 to 16:00. The highest value of AQI was detected at time observation 30,462 (23 June 2013, 06:00) with API value 663, which is within the emergency level during the dry summer monsoon.

For the hazardous category, the highest API value was detected at time observation 7,018 (20 October 2010, 10:00) with an API recorded value of 431. Certain data also fall within the hazardous level: on 19 January 2010 (12:00), 20 January 2010 (01:00-17:00), 22 June 2013 (22:00-24:00), and 23 June 2013 (01:00-22:00).

However, certain data experienced very unhealthy levels on October 2010 and June 2013, and unhealthy levels in October 2010, June 2013, July 2013, March 2014, September 2015, and October 2015.

From the analysis, especially for June 2013, Malaysia faced each API category of good, moderate, unhealthy, very unhealthy, hazardous, and emergency. This can be shown from the graphs in Figs 4(a-b). A study done by [13] shows several countries in the Southeast Asian region, including Brunei, Indonesia, Malaysia, Singapore, and Southern Thailand facing Southeast Asian haze occurring from 1 June 2013, with January-February and June-August every year being most likely to experience haze.

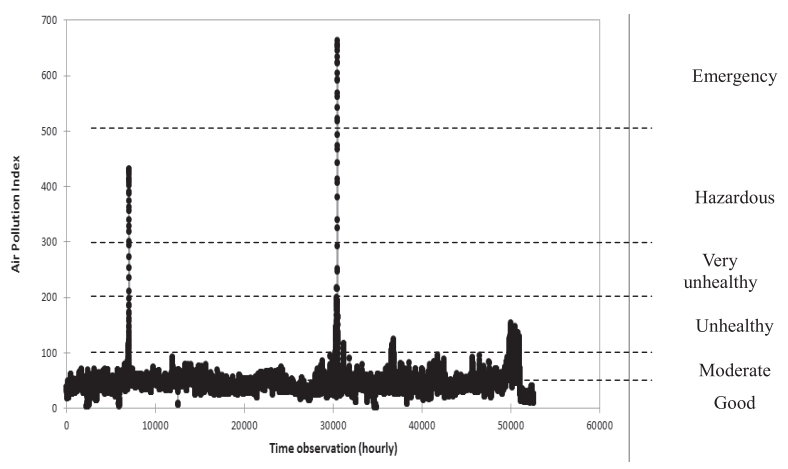

Fig. 3. API trend from 2010 to 2015 in Sekolah Menengah Teknik Muar, Johor.
According to [20], several areas in Johor in October 2010 faced high $\mathrm{PM}_{10}$ levels due to the transboundary haze from the land and forest fires in the Riau province in central Sumatera, Indonesia. The high $\mathrm{PM}_{10}$ present affected the value of API as API value in Malaysia was usually influenced by the suspended concentration of particulate matter $\left(\mathrm{PM}_{10}\right)$ due to the higher concentration value compared to others. A study done by [21] shows that there is a strong positive association between temperature and wind speed, which play a dominant role in controlling $\mathrm{PM}_{10}$ concentrations.

Figs 4 and 5 show annual frequencies of API categories, including good, moderate, unhealthy, very unhealthy, hazardous, and emergency - which change over the years. Each year from 2010 to 2015 shows a high frequency of API at good and moderate levels. However, API at the levels of unhealthy, very unhealthy, hazardous, and emergency as well as information absent also is present in those years.

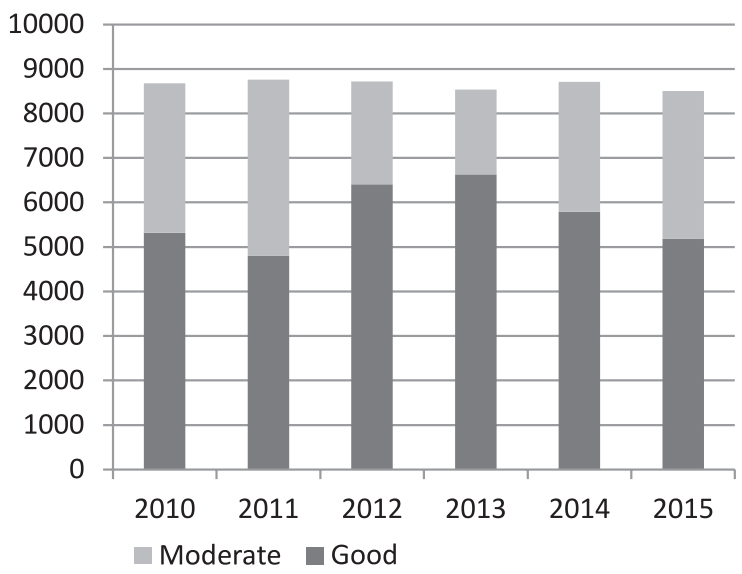

Fig. 4. Annual frequencies of API categories (good, moderate) at Sekolah Menengah Teknik Muar, Johor.

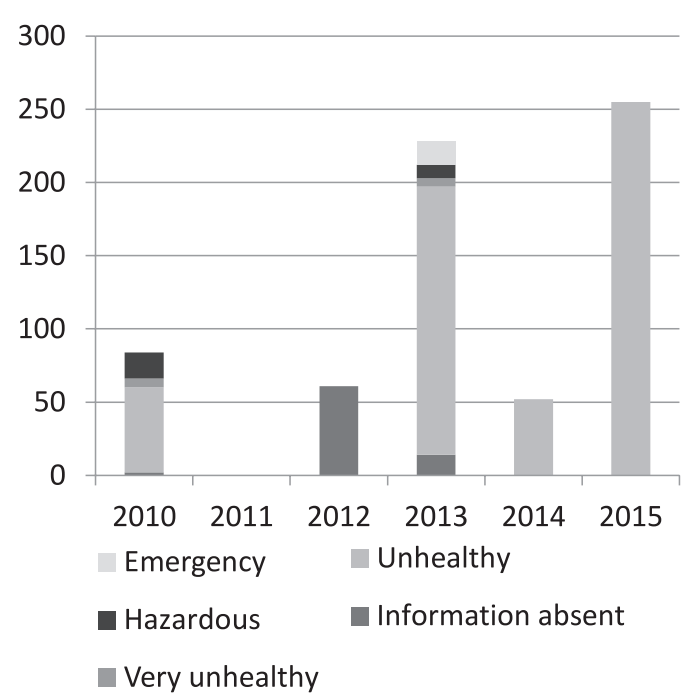

Fig. 5. Annual frequencies of API categories (unhealthy, very unhealthy, hazardous, emergency) at Sekolah Menengah Teknik Muar, Johor. 
API with unhealthy levels became dominant in 2015 with a frequency of 255. This was followed by 2013, 2010, and 2014 with frequencies of 183, 58, and 52, respectively. The very unhealthy levels of API were only present in 2010 and 2013 with a value of 6 for both levels. 2010 and 2013 also experienced hazardous API levels with a value of API 18 and 9, respectively.

From the analysis, 2010 and 2013 experienced the worst quality of air, especially in 2013. This is due to the haze episode mentioned earlier, where the air monitoring station at Sekolah Menengah Teknik Muar experienced a high level of API. Other studies also showed the worst air quality in 2013, where a study by [7] mentioned that the government of Malaysia declared a state of emergency in June 2013 due to the worst haze levels in 16 years. The thick smoke from the haze blanketed Peninsular Malaysia and reduced visibility nationwide.

In October 2010 some areas in Johor contributed to the higher $\mathrm{PM}_{10}$ due to land and forest fires in Riau Province in Central Sumatera, Indonesia [20]. However, some information was absent in 2012 and 2013. As 2013 had the worst quality of air, absent information is very important as each concentration of pollutants present might affect people as well as the environment. The absence of information might be due to equipment failure and human error.

\section{Conclusions}

API value reading is important for determining the level of air quality on that day. The worst quality of air can bring about harmful effects on human health, the environment, and also economic development. From the API reading obtained, the government can take action to reduce the worst air quality by taking actions. During a haze period where the highest API is recorded, the Malaysian government has taken necessary actions to diminish haze occurrence by restricting laws regarding open burning. Besides, cloud seeding also has been implemented by the government to ensure API at healthy levels. Industrial activities, which are a contributors to API level, also need attention. Enforcing regulations by the government regarding industrial activities can help API value at the healthy level.

\section{Acknowledgements}

This manuscript has been funded by the University Research Fund Grant (No. UniSZA/2016/DPU/01) and Universiti Sultan Zainal Abidin.

\section{References}

1. ABDULLAH A.M., SAMAH M.A.A., JUN T.Y. An Overview of the Air Pollution Trend in Klang Valley, Malaysia. Open Environmental Sciences, 6, 13, 2012.
2. LANZAFAME R., MONFORTE P., PATANÈ G., STRANO S. Trend analysis of Air Quality Index in Catania from 2010 to 2014. Energy Procedia, 82, 708, 2015.

3. DEPARTMENT OF ENVIRONMENT MALAYSIA (DOE). A guide to air pollutant index (API) in Malaysia. Department of Environment: Kuala Lumpur, Malaysia, 1, 2000.

4. OTT W.R., HUNT W.F.A. Quantitative Evaluation of the Pollutant Standards Index. Journal of the Air Pollution Control Association, 26 (11), 1050, 1976.

5. MOFIJUR M., RASUL M.G., HYDE J., AZAD A.K., MAMAT R., BHUIYA M.M.K. Role of biofuel and their binary (diesel-biodiesel) and ternary (ethanol-biodieseldiesel) blends on internal combustion engines emission reduction. Renewable and Sustainable Energy Reviews, 53, 265, 2016.

6. MABAHWI N.A., LEH O.L.H., OMAR D. Human Health and Wellbeing: Human health effect of air pollution. Procedia - Social and Behavioral Sciences, 153, 221, 2014.

7. MABAHWI N.A., LEH O.L.H., OMAR D. Urban Air Quality and Human Health Effects in Selangor, Malaysia. Procedia - Social and Behavioral Sciences, 170, $282,2015$.

8. RAHMAN N.H.A., LEE M.H., SUHARTONO LATIF M.T. Evaluation Performance of Time Series Approach for Forecasting Air Pollution Index in Johor, Malaysia. Sains Malaysiana, 45 (11), 1625, 2016.

9. DOMINICK D., JUAHIR H., LATIF M.T., ZAIN S.M., ARIS A.Z. Spatial assessment of air quality patterns in Malaysia using multivariate analysis. Atmospheric Environment, 60, 172, 2012.

10. AMRAN M.A., AZID A., JUAHIR H., TORIMAN M.E., MUSTAFA A.D., HASNAM C.N.C., AZAMAN F., KAMARUDIN M.K.A., SAUDI A.S.M., YUNUS K. Spatial Analysis of the Certain Air Pollutants Using Environmetric Techniques, 75 (1), 241, 2015.

11. AZID A., JUAHIR H., TORIMAN M.E., ENDUT A., RAHMAN M.N.A., KAMARUDIN M.K.A., LATIF M.T., SAUDI A.S.M.,, HASNAM C.N.C., YUNUS K. Selection of the Most Significant Variables of Air Pollutants Using Sensitivity Analysis. Journal of Testing and Evaluation, 44 (1), 376, 2016.

12. DEPARTMENT OF ENVIRONMENT MALAYSIA (DOE). Malaysian Environmental Quality Report. Department of Environment: Putrajaya, Malaysia, 1, 2004.

13. RAHMAN H.A. Haze Phenomenon in Malaysia: Domestic or Transboudry Factor?. $3^{\text {rd }}$ International Journal Conference on Chemical Engineering and its Applications (ICCEA'13) Sept. 28, 2013.

14. AZID A., JUAHIR H., TORIMAN M.E., ENDUT A., KAMARUDIN M.K.A., RAHMAN M.N.A., HASNAM C.N.C., SAUDI A.S.M., YUNUS K. Source Apportionment of Air Pollution: A Case Study in Malaysia. Jurnal Teknologi (Sciences \& Engineering), 72 (1), 83, 2015.

15. HOW C.Y., LING Y.E. The influence of $\mathrm{PM}_{2.5}$ and $\mathrm{PM}_{10}$ on Air Pollution Index (API). In Environmental Engineering, Hydraulics and Hydrology: Proceeding of Civil Engineering, Universiti Teknologi Malaysia, Johor, Malaysia, 3, 132, 2016.

16. TYAGI S., TIWARI S., MISHRA A., HOPKE P.K., ATTRI S.D., SRIVASTAVA A.K., BISHT D.S. Spatial variability of concentrations of gaseous pollutants across the National Capital Region of Delhi, India. Atmospheric Pollution Research, 7, 808, 2016.

17. LATINI G., GRIFONI R.C., PASSERINI G. Influence of meteorological parameters on urban and suburban air 
pollution. In Air Pollution X; Brebbia, C. A., MartinDuque, J. F., Eds. WIT Press: Southampton, UK, Volume 53, 753, 2002.

18. FOLBERTH G.A., BUTLER T.M., COLLINS W.J., RUMBOLD S.T. Megacities and climate change - A brief overview. Environmental Pollution, 203, 235, 2015.

19. AFROZ R., HASSAN M.N., IBRAHIM N.A. Review of air pollution and health impacts in Malaysia. Environmental Research, 92, 71, 2003.
20. DEPARTMENT OF ENVIRONMENT MALAYSIA (DOE). Malaysian Environmental Quality Report. Department of Environment: Putrajaya, Malaysia, 80, 2010. 21. MUNIR S., HABEEBULLAH T.M., SEROJI A.R., MORSY E.A., MOHAMMED A.M.F., SAUD W.A., ABDOU A.E.A., AWAD A.H. Modeling Particulate Matter Concentrations in Makkah, Applying a Statistical Modeling Approach. Aerosol and Air Quality Research, 13, 901, 2013. 